\title{
Room Temperature Ionic Liquid-based Microextraction for Pre-concentration of Cadmium and Copper from Biological Samples and Determination by FAAS
}

\author{
Ghulam A. Kandhro, ${ }^{a, b, c}$, Mustafa Soylak ${ }^{a *}$, Tasneem Gul Kazi ${ }^{b}$, Erkan Yilmaz ${ }^{a}$, and Hassan I. Afridi ${ }^{b}$ \\ ${ }^{a}$ Erciyes University, Fen Faculty, Department of Chemistry, 38039, Kayseri, Turkey \\ ${ }^{b}$ National Centre of Excellence in Analytical Chemistry, University of Sindh, \\ Jamshoro, 76080, Pakistan \\ ${ }^{\mathrm{c}}$ Department of Basic Sciences, Mathematics and Humanities, \\ Dawood College of Engineering and Technology, Karachi, 74800, Pakistan
}

\section{INTRODUCTION}

The influence and toxicity of trace metals such as cadmium (Cd) and copper $(\mathrm{Cu})$ on the environment and on human health are today receiving greater consideration in pollution and nutritional assessments (1-2). Cd is a nonessential element and plays no positive role for humans or animals. It is categorized as a predominantly toxic metal even at very low levels, and affects destruction of body organs, i.e., lungs, kidneys, and liver (3). The most significant anthropogenic sources of $\mathrm{Cd}$ are emission from industrial plants, such as steel works, zinc smelters, power stations, and incinerators $(1,4)$. The intake of Cd by humans takes place by respiration of polluted air or through ingestion of different foods $(5,6)$. The productions of free radicals, which deteriorate the physiological functions of the human body, are carried out by Cd through different mechanisms $(7,8)$. On the other hand, $\mathrm{Cu}$ is an essential trace element, plays vital roles in many biochemical reactions of the human organisms and in the metabolism of lipids, carbohydrates, proteins, and the synthesis of nucleic acids (9-10). Even though $\mathrm{Cu}$ is important for humans, high levels of $\mathrm{Cu}$ can be harmful and cause vomiting, nausea, diarrhea, irritation of throat and nose, and form toxic-free hydroxyl radicals resulting in cancer by destroying the DNA (11-12).

\footnotetext{
*Corresponding author.

E-mail: soylak@erciyes.edu.tr

Tel: + $903524374901 / 33150$

Fax: +903524374933
}

\section{ABSTRACT}

Room temperature ionic liquids (RTILs) are considered "Green Solvents" for their thermally stable and non-volatile properties. They are employed to replace traditional volatile organic solvents in solvent extraction, organic synthesis, and electrochemistry. In the present work, a simple, selective, sensitive and economical microextraction methodology was developed based on the separation and preconcentration of RTILs for trace cadmium (Cd) and copper (Cu) determination in biological samples. The $\mathrm{Cd}$ and $\mathrm{Cu}$ pre-concentration was established using the RTIL (1-butyl-3-methylimidazolium hexafluorophosphate

([C4mim][PF6]) with dithizone complex. For the quantitative recovery of $\mathrm{Cd}$ and $\mathrm{Cu}$, the effects of the parameters inducing the extraction efficiency and its subsequent determinations, i.e., $\mathrm{pH}$, amount of complexing reagent, volume of RTILs and dispersant solvent, sample volume, extraction time, and temperature were studied. For $\mathrm{Cd}$ and $\mathrm{Cu}$ determination under the optimized conditions, the detection limits (LOD) of 0.05 and $0.08 \mu \mathrm{g} / \mathrm{L}$ and quantification limits (LOQ) of 0.15 and $0.25 \mu \mathrm{g} / \mathrm{L}$, respectively, were obtained. An enrichment factor of 75 was achieved for both analytes and the relative standard deviation was $<3 \%$. BCR $144 \mathrm{R}$ sewage sludge of domestic origin certified reference material (CRM) was used for validation of the present method. The proposed RTIL microextraction method was applied for the pre-concentration of $\mathrm{Cd}$ and $\mathrm{Cu}$ in biological samples with satisfactory results.
The low levels of these analytes present in a complex sample matrix require a procedure that does not affect the accuracy and sensitivity of the analytical method selected. Therefore, a cleanup or enrichment step is most important. The procedures proposed in the literature for the separation and pre-concentration of $\mathrm{Cd}$ and $\mathrm{Cu}$ include cloud point extraction (CPE), solid phase extraction (SPE), coprecipitation, capillary microextraction, singledrop microextraction (SDME), and solid phase microextraction (SPME) (13-21), etc. Even though liquidliquid solvent extraction can efficiently reduce the limit of detection and remove interferences, it is tedious, time-consuming, and laborious, and requires high purity organic solvents. However, their removal after usage from the sample solution results in high risk of pollution to the environment (2223).

Within the last few years, room temperature ionic liquids (RTILs), which are considered green solvents, were used as alternative extractants for traditional liquidliquid extraction procedures (2425). Various problems related to the loss of solvent by evaporation as well as regular organic solvents were avoided by using ionic liquids (ILs) as substitute solvents. RTILs have high thermal stability even at elevated temperatures, good solubility for organic and inorganic compounds, and insignificant vapor pressure (26). The main benefit of ILs is that they are environmentally friendly for the extraction of elements (27). RTILs have been 
applied in SPE (28), hollow fiber membrane extraction (29), and liquid phase microextraction (30-31), and offer significantly high enrichment factors.

The aim of the present work was to establish a rapid, simple, novel, and highly efficient analytical procedure for $\mathrm{Cd}$ and $\mathrm{Cu}$ determination in biological samples using the combination of RTIL with flame atomic absorption spectrometry (FAAS). Dithizone is an extensively used complexing agent that can produce a complex with many metal ions. It acted as the ligand with methanol as the dispersant solvent for the Cd and Cu pre-concentration in biological samples. The influence of several experimental parameters on the extraction of $\mathrm{Cd}$ and $\mathrm{Cu}$ were investigated to examine the extraction behavior of ionic liquids.

\section{EXPERIMENTAL}

\section{Instrumentation}

A PerkinElmer@ Model 3110 flame atomic absorption spectrometer, equipped with a $10-\mathrm{cm}$ airacetylene burner, was used for the determination of $\mathrm{Cd}$ and $\mathrm{Cu}$ (PerkinElmer, Inc., Shelton, CT, USA). At 12.5 and $15 \mathrm{~mA}$, the hollow cathode lamps of $\mathrm{Cd}$ and $\mathrm{Cu}$ were operated with a $0.7 \mathrm{~nm}$ spectral bandwidth. The analytical wavelengths were set at 228.8 and $324.8 \mathrm{~nm}$, respectively. A Sartorius Model PT-10 glass-electrode was used to establish the $\mathrm{pH}$ levels (Sartorius Co., Goettingen, Germany). An ALC PK Model 120 centrifuge machine and a Vortex 3000 ANA Shaker (Wiggen Hauser, Salenger, Malaysia) were used. For the purification of water, a Model RO 180 (Human Corporation, Korea) reverse osmosis water purification system was used to achieve $1 \mu \mathrm{S} / \mathrm{cm}$ water conductivity. The instrumental settings are listed in Table I.

\section{Standards and CRM}

Standard solutions of $\mathrm{Cd}$ and $\mathrm{Cu}$ were prepared by dilution of the stock solution $(1000 \mathrm{mg} / \mathrm{L})$, obtained from Merck, Darmstadt, Germany. The standard solutions were prepared by stepwise dilution of the stock solution. Certified reference material (CRM) BCR 144R sewage sludge of domestic origin was provided by the Community Bureau of Reference (Geel, Belgium).

\section{Chemicals, Reagents, and Glassware}

In this study, all reagents used were analytical grade. Concentrated nitric acid $\left(\mathrm{HNO}_{3}\right.$, purity 65\%) and methanol were obtained from Merck (Germany) and Sigma Aldrich (St. Louis, USA), respectively. Ionic liquid (IL) 1-butyl-3-methylimidazolium hexafluorophosphate ([C4mim][PF6]) was obtained from Merck. A $0.1 \%$ (w/v) dithizone was obtained from Riedel-deHaen (Sleeze, Germany). The dithizone solution was prepared in methanol. A $0.1 \mathrm{M}$ phosphate buffer solution was prepared from di-sodium hydrogen phosphate $\left(\mathrm{Na}_{2} \mathrm{HPO}_{4}\right)$ in reverse osmosis water, and a $\mathrm{pH}$ range of 4-10 was prepared with (0.1 M) $\mathrm{HNO}_{3} / \mathrm{NaOH}$. All laboratory glassware and plastic containers used in the present experimental work were kept in $10 \%(\mathrm{v} / \mathrm{v}) \mathrm{HNO}_{3}$ and, prior to use, were rinsed with reverse osmosis water.

\section{Sample Preparation}

A 1-mL aliquot of sample solution was taken and $\mathrm{Cd}$ and $\mathrm{Cu}$ was instantly determined and pre-concentrated using the RTIL method.

\section{Atomic Apectroscopy 1 Vol. 33(5), Sept./Oct. 2012}

Portions of $1 \mathrm{~g}$ human scalp hair and $2 \mathrm{~mL}$ of urine samples were placed into a PTFE beaker $(10 \mathrm{~mL})$. Then, $10 \mathrm{~mL}$ of concentrated $\mathrm{HNO}_{3}$ was added and the solution kept standing overnight. The solution was evaporated and $10 \mathrm{~mL}$ of $\mathrm{HNO}_{3}$ and $\mathrm{H}_{2} \mathrm{O}_{2}$ (2:1) was added, then heated to near dryness. The residue was dissolved in $0.2 \mathrm{M} \mathrm{HNO}_{3}$. Before analysis, the phosphate buffer solution was used to adjust to $\mathrm{pH}$ 9. The certified reference material (CRM) BCR 144R sewage sludge of domestic origin and the blank samples were prepared using the same method as for the biological samples in order to assess Cd and $\mathrm{Cu}$ concentrations with the reagents.

\section{Recommended RTIL Procedure}

For the enrichment of $\mathrm{Cd}$ and $\mathrm{Cu}, 15-\mathrm{mL}$ aliquots of standard solution containing the $\mathrm{Cd}$ and $\mathrm{Cu}$ analyte in the range of $0.12-100 \mu \mathrm{g} / \mathrm{L}$, three replicate samples of $10 \mathrm{~mL}$ of BCR 144R and triplicate samples of each real biological (scalp hair and urine) sample were taken into 50-mL graduated centrifuge tubes. Then, $3 \mathrm{~mL}$ of different buffers were added to adjust the $\mathrm{pH}$ in the range of 4-10. The $\mathrm{pH}$ of the solution was adjusted to the desired $\mathrm{pH}$ by the addition of $1 \mathrm{M} \mathrm{HCl}$ and/or $\mathrm{NaOH}$. After adjusting the $\mathrm{pH}$, 300-1200 $\mu \mathrm{L}$ dithizone solution (0.01\%), $100 \mu \mathrm{L}$ of each methanol and $\left(\left[\mathrm{C}_{4} \mathrm{mim}\right]\left[\mathrm{PF}_{6}\right]\right)$ were added as disperser and extractant solvents, respectively. This step resulted in a cloudy solution (water, methanol, and ([C4mim] $[\mathrm{PF} 6]))$ in the tube. The centrifuge tubes were shaken carefully and gradually for a few

\begin{tabular}{|c|c|c|c|}
\hline \multicolumn{4}{|c|}{$\begin{array}{c}\text { TABLE I } \\
\text { Instrument Settings }\end{array}$} \\
\hline \multicolumn{4}{|c|}{ Parameters } \\
\hline Elements & Wavelength $(\mathrm{nm})$ & Slit width (nm) & Lamp current ( $\mathrm{mA})$ \\
\hline $\mathrm{Cd}$ & 228.8 & 0.7 & 4 \\
\hline $\mathrm{Cu}$ & 324.8 & 0.7 & 30 \\
\hline
\end{tabular}


seconds and allowed to stand for 15 minutes. Then the cloudy solution was centrifuged for 10 minutes at $4000 \mathrm{rpm}$. This allowed the formation of two well-defined phases, and dispersive droplets of IL were sedimented at the bottom of the centrifuge tube. After enrichment, the upper aqueous phase was decanted, the IL phase dissolved in $200 \mu \mathrm{L}$ of concentrated $\mathrm{HNO}_{3}$, and then introduced into the FAAS using a home-made micro-sample aspiration system. For the respective analyte determinations, the samples were introduced into the nebulizer of the FAAS by using the home-made microsample aspiration system. In this system, $100 \mu \mathrm{L}$ of the sample was injected into a mini home-made Teflon ${ }^{\circledR}$ funnel with an Eppendorf ${ }^{\circledR}$ pipette. The Teflon funnel was connected to the nebulizer with capillary tubing $(19,32)$.

Calibration of $\mathrm{Cd}$ and $\mathrm{Cu}$ was prepared by subjecting the aqueous standards to the same RTIL procedure. A blank submitted to the RTIL was measured similar to the calibration solution of the standards, CRM, and real biological samples. The validation and accuracy of the proposed RTIL method were checked by using the CRM BCR 144R sewage sludge of domestic origin for both analytes.

\section{RESULTS AND DISCUSSION}

The RTILs procedure in comparison to conventional dispersive liquid phase microextraction was carried out using a single solvent reagent. RTILs and dispersive liquid phase microextraction procedures substantially increase the surface area of the extraction solvent, and the contact area between extraction solvent and analytes enhances the recovery of the analytes. In addition, ILs are used as an alternative to toxic organic solvents in RTILs as compared to dispersive liquid-phase microextraction (DLLME). Some significant experimental factors that would affect the enrichment efficiency were studied in order to achieve optimum extraction recovery.

\section{Effect of $\mathbf{p H}$}

The $\mathrm{pH}$ plays a distinctive role on metal-ligand development and affects production of the complex and its consequent extraction. The influence of $\mathrm{pH}$ on optimum complex production for the extraction of $\mathrm{Cd}$ and $\mathrm{Cu}$ was studied on replicate subsamples of standards or real samples by altering the $\mathrm{pH}$ of the aqueous solution ranging from 4-10. The results illustrated in Figure 1 show that the $\mathrm{Cd}$ and $\mathrm{Cu}$ recoveries in the presented system decrease with a $\mathrm{pH}$ range of 4-7,

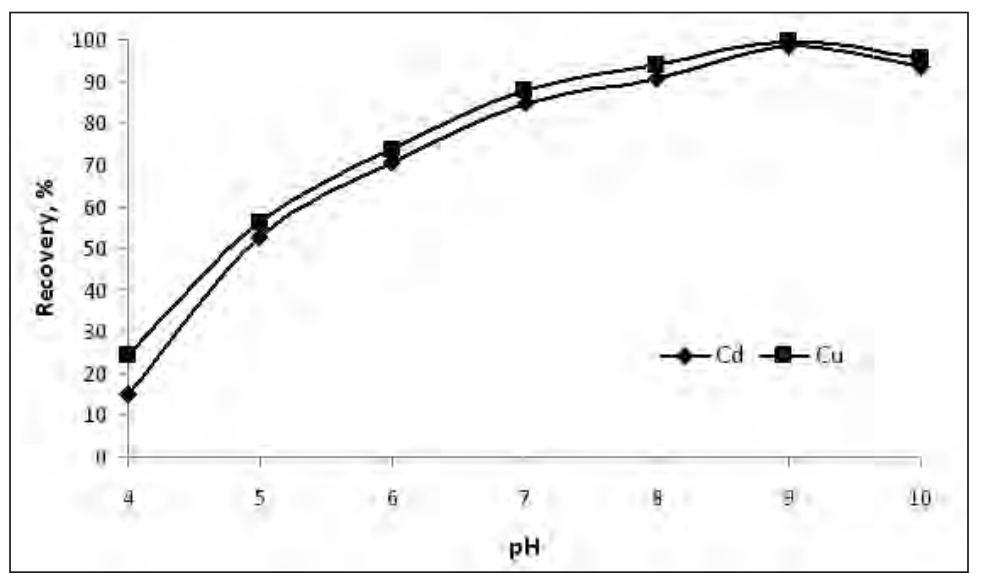

Fig. 1. Effect of $\mathrm{pH}$ on the (\%) recovery of Cd and Cu: $1000 \mu \mathrm{L}$ of a dithizone $(0.01 \%), 100 \mu \mathrm{L}$ of ILs and methanol, centrifugation at 10 minutes at $4000 \mathrm{rpm}$.

then increases with a $\mathrm{pH}$ higher than 7. Optimum extraction efficiency was obtained at $\mathrm{pH} 9$. To prevent hydrolyzation of the metal ion at a higher $\mathrm{pH}$ value, the $\mathrm{pH}$ of 9 was selected for both analytes. The metal chelator is in neutral form at a lower $\mathrm{pH}$, and distributes or mixes in the organic phase. This leads to a very low level metal chelate complex because there is only a limited amount of deprotonated chelator present for the production of the complex. On the other hand, at a higher $\mathrm{pH}$, a high level of deprotonated chelator leads to a high level of metal chelate complex, resulting in high extraction efficiency.

\section{Effect of Dithizone Concentra- tion}

Dithizone is a strong chelating ligand for metal ion extraction because it can produce stable complexes with many metal ions under appropriate conditions. The recovery of $\mathrm{Cd}$ and $\mathrm{Cu}$ increased with an increase in $0.01 \%(\mathrm{w} / \mathrm{v})$ dithizone from 400 to $1200 \mu \mathrm{L}$, and remained constant with a further increase in the dithizone level. At $1000 \mu \mathrm{L}$, optimum recovery of $\mathrm{Cd}$ and $\mathrm{Cu}$ was obtained and $0.01 \%$ dithizone was chosen for further experiments to avoid the competitive chelation of matrix ions in real biological samples (see Figure 2). Optimum extraction efficiency was dependent on the concentration of the complexing agent. When the volume of dithizone was $>1000 \mu \mathrm{L}$, the analytical signal remained constant.

\section{Effect of Volume of Ionic Liquid}

The volume of the extractant is an important factor in conventional liquid phase extraction and significantly affects the extraction efficiency of the analytes. In the present work, $\left(\left[\mathrm{C}_{4} \mathrm{mim}\right]\left[\mathrm{PF}_{6}\right]\right)$ was chosen as the extraction solvent due to its hydrophobicity. The volume of $\left(\left[\mathrm{C}_{4} \mathrm{mim}\right]\left[\mathrm{PF}_{6}\right]\right)$ was opti- 
mized in the range of 50-150 $\mu \mathrm{L}$. The results in Figure 3 show that the $\mathrm{Cd}$ and $\mathrm{Cu}$ recoveries increased along with an increase in the volume of $\left(\left[\mathrm{C}_{4} \mathrm{mim}\right]\left[\mathrm{PF}_{6}\right]\right)$ from 50 to $100 \mu \mathrm{L}$, while the extraction efficiency of $\left(\left[\mathrm{C}_{4} \mathrm{mim}\right]\left[\mathrm{PF}_{6}\right]\right)$ remained constant when the volume was $>100 \mu \mathrm{L}$. Therefore, $100 \mu \mathrm{L}$ IL was chosen in order to achieve perfect analytical characteristics.

\section{Disperser Solvents and Their Effects}

The disperser solvent must be miscible in both extractant and aqueous phase and should have good dispersive ability. Therefore, methanol, acetone, ethanol, and acetonitrile were used as disperser solvents. The influence of these solvents on the extraction efficiency of RTILs was determined using different volumes of each disperser solvent with $100 \mu \mathrm{L}$ of ([ $\left.\mathrm{C}_{4} \mathrm{mim}\right]\left[\mathrm{PF}_{6}\right]$ ) and $0.01 \%$ dithizone. The results indicated that among the four disperser solvents, methanol has the highest extraction efficiency for $\mathrm{Cd}$ and $\mathrm{Cu}$. Thus, methanol was selected as the disperser solvent for further studies.

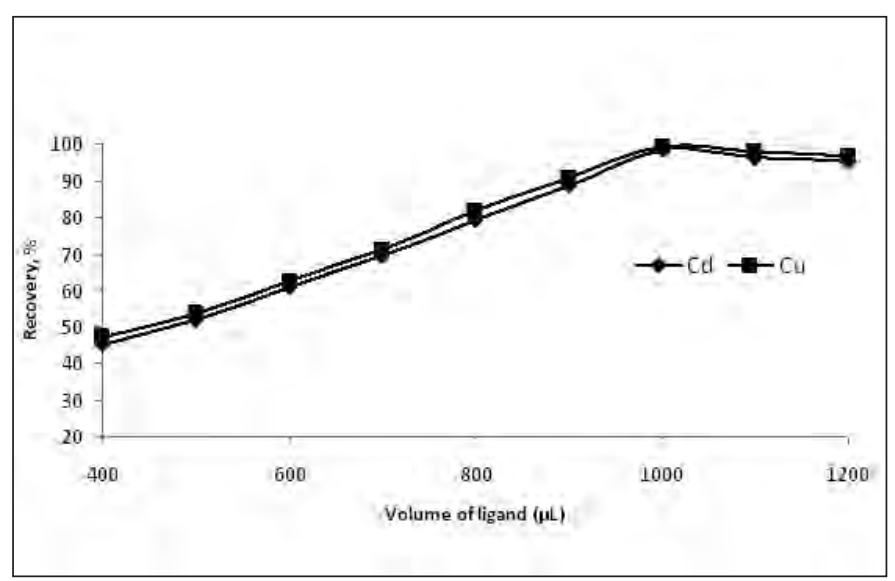

Fig. 2. Effect of dithizone concentration on the (\%) recovery of $\mathrm{Cd}$ and $\mathrm{Cu}: \mathrm{pH}$ 9, $100 \mu \mathrm{L}$ of ILs and methanol, centrifugation at 10 minutes at $4000 \mathrm{rpm}$.

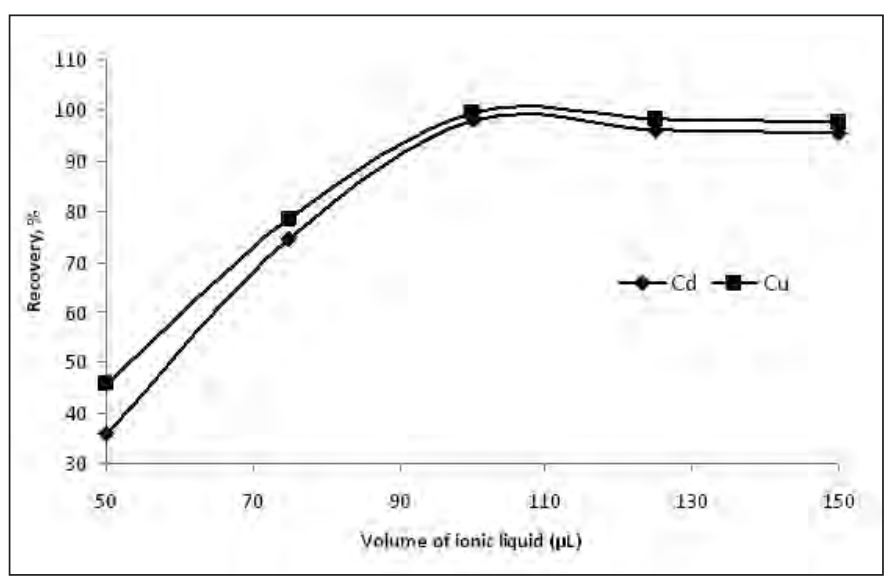

Fig. 3. Effect of ILs volume on the (\%) recovery of Cd and Cu: $1000 \mu \mathrm{L}$ of $0.01 \%$ of a dithizone, $\mathrm{pH}$ 9, $100 \mu \mathrm{L}$ of methanol, centrifugation at 10 minutes at $4000 \mathrm{rpm}$.

\section{Atomic Apectroscopy \\ $\circlearrowleft$ Vol. 33(5), Sept./Oct. 2012}

The effect of volume of methanol on the extraction efficiency of $\mathrm{Cd}$ and $\mathrm{Cu}$ was also studied. To attain the optimum volume of methanol, different volumes (25-150 $\mu \mathrm{L})$ of methanol were tested. The results showed that the extraction efficiency increased with an increase in the volume of methanol up to $100 \mu \mathrm{L}$, then reduced with a further increase in methanol volume (see Figure 4). It can be concluded that a minimum volume of methanol results in $\left(\left[\mathrm{C}_{4} \mathrm{mim}\right]\left[\mathrm{PF}_{6}\right]\right)$ not being dispersed well and consequently decreases the extraction efficiency. On the other hand, the solubility of the metal-dithizone complex in the aqueous phase increases with a higher volume of methanol but reduces the extraction efficiency. For further studies, $100 \mu \mathrm{L}$ of methanol was chosen as the optimum volume.

\section{Sample Volume}

The effects of sample volume with a constant amount of $100 \mu \mathrm{L}$ of $\left(\left[\mathrm{C}_{4} \mathrm{mim}\right]\left[\mathrm{PF}_{6}\right]\right)$ and methanol on the extraction of $\mathrm{Cd}$ and $\mathrm{Cu}$ were studied from 10.0 to $50.0 \mathrm{~mL}$. By increasing the sample volume to $>20 \mathrm{~mL}$, the extraction efficiency of the respective analytes decreased. 
The optimal extraction recovery was found at $15 \mathrm{~mL}$. Therefore, a sample volume of $15 \mathrm{~mL}$ was selected for subsequent work.

\section{Effects of Centrifugation Rate and Time}

The centrifugation rate and time that induced the pre-concentration of ILs from the aqueous phase was investigated from 5 to 20 minutes at the 2500-5000 rpm range, respectively. The analytical signals of $\mathrm{Cd}$ and $\mathrm{Cu}$ increased by increasing the extraction time up to 10 minutes and then keeping the time constant. Mass transfer is a timedependent process and the maximum integrated absorbance is attained when the system is at equilibrium. However, it takes time for a system to reach complete equilibrium. The extraction time was investigated by monitoring the variation of the integrated absorbance. The integrated absorbance increases with an increase in extraction time up to 10 minutes, and after 10 minutes the increase becomes slower. Therefore, to avoid dropwise dissolution, the extraction time of 10 minutes was selected for quantitative complex formation of the analytes (3). Greater extraction efficiency was obtained at $4000 \mathrm{rpm}$, and above this centrifugation rate, there was no effect on the extraction efficiency.

TABLE II

Effect of Interfering Ions on the Recovery of Cd and Cu Using RTILs

\begin{tabular}{|c|c|c|c|c|}
\hline \multirow{2}{*}{$\begin{array}{l}\text { Interferent } \\
\text { Ions }\end{array}$} & \multirow{2}{*}{$\begin{array}{l}\text { Conc. } \\
(\mu \mathrm{g} / \mathrm{mL})\end{array}$} & \multirow{2}{*}{$\begin{array}{l}\text { Added } \\
\text { Ions }\end{array}$} & \multicolumn{2}{|c|}{ \% Recovery } \\
\hline & & & $\mathrm{Cd}$ & $\mathrm{Cu}$ \\
\hline $\mathrm{Fe}^{3+}$ & 25 & $\mathrm{Fe}\left(\mathrm{NO}_{3}\right)_{3} \cdot 9 \mathrm{H}_{2} \mathrm{O}$ & 98.4 & 95.6 \\
\hline $\mathrm{Zn}^{2+}$ & 25 & $\mathrm{Zn}\left(\mathrm{NO}_{3}\right)_{2} \cdot 6 \mathrm{H}_{2} \mathrm{O}$ & 96.9 & 97.4 \\
\hline $\mathrm{Pb}^{2+}$ & 25 & $\mathrm{~Pb}\left(\mathrm{NO}_{3}\right)_{2} \cdot 6 \mathrm{H}_{2} \mathrm{O}$ & 95.7 & 93.1 \\
\hline $\mathrm{Na}^{+}$ & 2000 & $\mathrm{NaNO}_{3}$ & 98.7 & 97.2 \\
\hline $\mathrm{K}^{+}$ & 2000 & $\mathrm{KCl}$ & 97.8 & 96.3 \\
\hline $\mathrm{Ca}^{2+}$ & 250 & $\mathrm{Ca}\left(\mathrm{NO}_{3}\right)_{2} \cdot 4 \mathrm{H}_{2} \mathrm{O}$ & 96.9 & 93.4 \\
\hline $\mathrm{Mg}^{2+}$ & 250 & $\mathrm{Mg}\left(\mathrm{NO}_{3}\right)_{2} \cdot 4 \mathrm{H}_{2} \mathrm{O}$ & 89.3 & 90.4 \\
\hline $\mathrm{Cl}^{-}$ & 2000 & $\mathrm{KCl}$ & 97.5 & 94.8 \\
\hline $\mathrm{SO}_{4}{ }^{2-}$ & 2500 & $\mathrm{Na}_{2} \mathrm{SO}_{4}$ & 91.4 & 91.2 \\
\hline
\end{tabular}

\section{Influences of Concomitants}

The reliability of the proposed pre-concentration method on the recovery of $\mathrm{Cd}$ and $\mathrm{Cu}$ was studied in the presence of possible concomitant ions. The results listed in Table II demonstrated that the existence of greater amounts of interfering ions had no noticeable effect on the recovery of the respective analytes within a $\pm 5 \%$ error. The influence of interfering ions present up to $5000 \mu \mathrm{g} / \mathrm{mL}$ each was insignificant on the pre-concentration of the analytes. The results indicate that the proposed pre-concentration procedure can be useful in the analysis of biological samples without any systematic error.

\section{Calibration, Precision, and Detection Limits}

Calibration graphs were established for $\mathrm{Cd}$ and $\mathrm{Cu}$ by enrichment of the sample with $0.01 \%$ dithizone, ionic liquid, and disperser solvent in a medium buffered at $\mathrm{pH}$ 9. Calibrations were achieved with a series of $\mathrm{Cd}$ and $\mathrm{Cu}$ standards after subjecting to RTIL. The calibration curve equations after the pre-concentration method for $\mathrm{Cd}$ and $\mathrm{Cu}$, respectively, were :

$(\mathrm{A}=0.0324 \mathrm{C}(\mathrm{Cd})+0.0024)$ and $(\mathrm{A}=0.0193 \mathrm{C}(\mathrm{Cu})+0.001)$,

where $\mathrm{A}$ is the absorbance and $\mathrm{C}$ is the concentration of the analyte in the extraction solvent. The correlation coefficients of the equations were 0.993 and 0.995 for $\mathrm{Cd}$ and $\mathrm{Cu}$, respectively, which shows that a good linear regression was obtained between absorbance and concentration.

The limits of detection (LOD) and limits of quantification (LOQ) for $\mathrm{Cd}$ and $\mathrm{Cu}$ were estimated as follows: $\mathrm{LOD}=3 \times \mathrm{s} / \mathrm{m}$ and $\mathrm{LOD}=$ $10 \times \mathrm{s} / \mathrm{m}$, respectively, where $\mathrm{s}$ is the standard deviation of 10 measurements of the blank and $\mathrm{m}$ is the slope of the calibration graph. The LOD and LOQ of $\mathrm{Cd}$ and $\mathrm{Cu}$, respectively, was found to be $(0.05$ and 0.08$)$ and $(0.15$ and 0.25$) \mu \mathrm{g} / \mathrm{L}$. The relative standard deviations (RSDs) of the proposed method were 2.2 and $2.9 \%$ for both analytes by measuring the standard solution $(n=5)$. The enrichment factors (EF) for $\mathrm{Cd}$ and $\mathrm{Cu}$ were found to be 75 , respectively, designed as the slope ratio of the two calibration curves of the standard with microextraction and without microextraction.

\section{Accuracy of Proposed Method}

For verification of accuracy, validation, and precision of the proposed method, CRM BCR 144R sewage sludge of domestic origin, triplicate samples, procedural and reagent blanks were applied for $\mathrm{Cd}$ and $\mathrm{Cu}$ determination. The percentage recoveries of $\mathrm{Cd}$ and $\mathrm{Cu}$ in the CRM samples by RTILs were in the 98.4-98.7\% range (see Table III).

The analytical results were in good

TABLE III

Analytical Results of $\mathrm{Cd}$ and $\mathrm{Cu}$ Determination in CRM BCR 144R (Sewage Sludge of Domestic Origin) sing RTILs $(\mathrm{n}=3)$ in $(\mathrm{mg} / \mathrm{Kg})$

\begin{tabular}{cccc}
\hline & $\begin{array}{c}\text { Certified Value } \\
\mathrm{x} \pm \mathrm{s}^{\mathrm{a}}\end{array}$ & $\begin{array}{c}\text { Observed Value } \\
\mathrm{x} \pm \mathrm{s}^{\mathrm{a}}\end{array}$ & $\begin{array}{c}\text { Recovery }^{\mathrm{b}} \\
(\%)\end{array}$ \\
\hline $\mathrm{Cd}$ & $1.84 \pm 0.02$ & $1.81 \pm 0.04$ & 98.4 \\
$\mathrm{Cu}$ & $300 \pm 7.5$ & $296 \pm 8.6$ & 98.7 \\
\hline
\end{tabular}

${ }^{\mathrm{a}}$ mean \pm standard deviation $(\mathrm{n}=10)$.

$\mathrm{b}(\%)$ Recovery $=[$ Observed value $] /[$ Certified value $] \times 100$. 


\section{A Amic $_{\text {Soectroscopy }}^{\text {tom }}$}

agreement with the CRMs and the presented values, and no significant differences were detected ( $p>0.05)$. The mean levels for $\mathrm{Cd}$ and $\mathrm{Cu}$ differed by less than $1-2 \%$ from the certified values. These results demonstrate the validity of the proposed procedure for $\mathrm{Cd}$ and $\mathrm{Cu}$ preconcentration.

\section{Comparative Data of Analytical Characteristics of DLLME}

A comparison of the proposed procedure with other described pre-concentration procedures for $\mathrm{Cd}$ and $\mathrm{Cu}$ pre-concentration is summarized in Table IV. The developed RTIL procedures have relatively lower LOD $(0.05$ and 0.08 $\mu \mathrm{g} / \mathrm{L}$ ) and higher $\mathrm{EF}$ (75) for $\mathrm{Cd}$ and $\mathrm{Cu}$, respectively, than some of the other methods listed in Table IV and require only $10 \mathrm{~mL}$ of sample solution. This is useful for pre-concentration of both $\mathrm{Cd}$ and $\mathrm{Cu}$ at trace levels in real biological samples. As shown in Table IV, the proposed RTIL method, compared with literature data, indicates that the RSD, LOD/LOQ, and the EF of the present study are comparatively better than in previously described studies $(3,22-23,33-40)$.

\section{Applications}

The RTIL method is suitable for the determination of $\mathrm{Cd}$ and $\mathrm{Cu}$ in biological samples (scalp hair and urine) as listed in Table V. The analytical applicability of the proposed methodology was verified by measuring the $\mathrm{Cd}$ and $\mathrm{Cu}$ levels in $10 \mathrm{~mL}$ each of CRMs and biological samples. The samples were pre-concentrated with $0.01 \%$ dithizone and $100 \mu \mathrm{L}$ of each IL and methanol, respectively. The results show that the proposed RTILs can be successfully applied for the separation and pre-concentration of biological samples.

TABLE IV

Comparison of Analytical Characteristics of the RTILs With Other Reported Methods for $\mathrm{Cd}$ and $\mathrm{Cu}$ Pre-concentration

\begin{tabular}{llrcccc}
\hline System & $\begin{array}{c}\text { Analysis } \\
\text { Method }\end{array}$ & $\begin{array}{c}\text { Enrichment } \\
\text { Factor }\end{array}$ & $\begin{array}{c}\text { RSD } \\
(\%)\end{array}$ & $\begin{array}{c}\text { Linear Range } \\
(\mu \mathrm{g} / \mathrm{L})\end{array}$ & $\begin{array}{c}\text { LOD } \\
(\mu \mathrm{g} / \mathrm{L})\end{array}$ & $\begin{array}{c}\text { Refer- } \\
\text { ence }\end{array}$ \\
\hline Cd & & & & & & \\
On-line SPE & GFAAS & 24.6 & 3.2 & $0.006-0.3$ & 0.0028 & $(33)$ \\
CPE & FAAS & 5 & $0.8-3.0$ & $3-300$ & 1.00 & $(34)$ \\
DLLME & GFAAS & 122 & 2.9 & $0.002-0.021$ & 0.0005 & $(23)$ \\
SDME & GFAAS & 65 & 7.4 & $0.01-1$ & 0.0007 & $(3)$ \\
\hline Cu & & & & & & \\
On-line SPE & FAAS & 560 & 2.1 & $0.16-12$ & 0.04 & $(35)$ \\
CPE & FAAS & 64.3 & 1.6 & $0.27-100$ & 0.27 & $(36)$ \\
DLLME & FAAS & 42 & 5.1 & $50-2000$ & 3 & $(37)$ \\
IL-SDME & UV-Vis. & 33 & 3.4 & - & 0.15 & $(22)$ \\
\hline RTILs & & & & & & Present \\
Cd/Cu & FAAS & 75 & $2.2 / 2.9$ & $0.12-100$ & $0.05 / 0.08$ & study \\
\hline
\end{tabular}

TABLE V

Analytical Results of $\mathrm{Cd}$ and $\mathrm{Cu}$ Determination in Standard and Spiked Biological Samples by RTILs $(n=3)$ in $\mu \mathrm{g} / \mathbf{m L}$

\begin{tabular}{cccccc}
\hline & $\begin{array}{l}\text { Spiked } \\
\text { Sample }\end{array}$ & Found & $\begin{array}{c}\text { Recovery } \\
(\%)\end{array}$ & Found & $\begin{array}{c}\text { Recovery } \\
(\%)\end{array}$ \\
\hline \multirow{3}{*}{ Cd } & Hair sample & & Urine sample & \\
& 0 & $1.76 \pm 0.07^{\mathrm{a}}$ & - & $0.015 \pm 0.002$ & - \\
& 5 & $6.65 \pm 0.02$ & 98 & $5.01 \pm 0.08$ & 99.9 \\
& 10 & $11.7 \pm 0.36$ & 100 & $10.1 \pm 0.25$ & 100.0 \\
& 20 & $21.4 \pm 0.62$ & 98 & $20.1 \pm 0.42$ & 100.1 \\
\hline $\mathrm{Cu}$ & 0 & $20.3 \pm 0.52$ & - & $0.25 \pm 0.05$ & - \\
& 5 & $25.2 \pm 0.56$ & 99 & $5.13 \pm 0.12$ & 97.4 \\
& 10 & $30.1 \pm 0.78$ & 98 & $10.1 \pm 0.32$ & 98.8 \\
& 20 & $40.2 \pm 0.86$ & 100 & $20.2 \pm 0.51$ & 99.7 \\
\hline
\end{tabular}

${ }^{a}$ mean \pm standard deviation $(x \pm s)(n=4)$.

\section{CONCLUSION}

An effective procedure for the pre-concentration and separation of $\mathrm{Cd}$ and $\mathrm{Cu}$ in biological samples is described using room temperature ionic liquids (RTILs) consisting of $1000 \mu \mathrm{L}$ of dithizone, $100 \mu \mathrm{L}$ each of IL and methanol, followed by FAAS determination. The detection limits (LODs) for $\mathrm{Cd}$ and $\mathrm{Cu}$ were
0.05 and $0.08 \mu \mathrm{g} / \mathrm{L}$ and the quantification limits (LOQs) were 0.15 and $0.25 \mu \mathrm{g} / \mathrm{L}$, respectively. In comparison to traditional extraction methods, the proposed method is rapid and simple, cost-effective, environmentally save, offers an enhancement factor of 75 , enhanced sensitivity, and requires no toxic organic solvents. The greater toler- 
ance of coexisting ions and excellent analytical performance shows that the developed method is applicable for the investigation of trace elements in biological samples.

\section{ACKNOWLEDGMENT}

Dr. Ghulam A. Kandhro is grateful to TUBITAK for the "2216 Research Fellowship Programme for Foreign Citizens" and financial support. The authors are also grateful for the financial support from the Unit of the Scientific Research Project of Erciyes University (Project no: FBA-12-3822).

Received July 2, 2012.

\section{REFERENCES}

1. M. Soylak and L. Elci, J. Trace Microprobe Techn. 18, 397 (2000).

2. R. Khani, F. Shemirani and B. Majidi, Desalination 266, 238 (2011).

3. Z. Fan and W. Zhou, Spectrochim. Acta B 61, 870 (2006).

4. J.L. Manzoori, H. A-Zadeh and M. Amjadi, Talanta 71, 582 (2007).

5. H.H. Aydin, C. Coker and B. Ersoz, Turk. J. Med. Sci. 31, 127 (2001).

6. M. Ikeda, Z.W. Zhang, S. Shimbo, T. Watanabe, H. Nakatsuka, C.S. Moon, N. Matsuda-Inoguchi, K. Higashikawa, Sci. Total Environ. 249, 373 (2000).

7. S.J. Stohs, D. Bagchi, E. Hassoun and M. Bagchi, J. Environ. Pathol. Toxicol. Oncol. 19, 201 (2000).

8. T. Tsukahara, T. Ezaki, J. Moriguchi, K. Furuki, S. Shimbo, N. MatsudaInoguchi, M. Iked, Sci. Total Environ. 305, 41, (2003).

9. T.G. Kazi, G.A. Kandhro, H.I. Afridi, N. Kazi, J.A. Baig, M.B. Arain, A.Q. Shah, N. Syed, S.K. Wadhwa, N.F. Kolachi, S. Khan, Biol. Trace Elem. Res. 134, 265 (2009).

10. A.M. Viegas-Crespo, M.L. Pavao, O. Paulo, V. Santos, M.C. Santos and J. Neve, J. Trace Elem. Med. Biol. 14, 1 (2000).
11. T. Theophanides and $\mathrm{J}$. Anastassopoulou, Crit. Rev. Oncol./Hematol. 42, 57 (2002).

12. D. Mendil, Ö.D. Uluözlü, M. Tüzen and M. Soylak, J. Hazard. Mater. 165, 724 (2009).

13. C. Duran, A. Gundogdu, V.N. Bulut, M. Soylak, L. Elci, H.B. Senturk, M. Tufekci, J. Hazard. Mater. 146, 347 (2007).

14. F.A. Aydin and M. Soylak, Talanta 73, 134 (2007).

15. S. Saracoglu, M. Soylak and L. Elci, Trace Elem. Electrolytes 18, 129 (2001).

16. F. Armagan, M. Soylak, L. Elci and M. Dogan, J. Trace Microprobe Tech. 20, 15 (2002).

17. S. Candir, I. Narin and M. Soylak, Talanta 77, 289 (2008).

18. H. Jiang and B. Hu, Microchim. Acta 161, 101 (2008).

19. J.N. Kamau, J.C. Ngila, A. Kindness and T. Bush, Anal. Lett. 44, 1891 (2011).

20. M. Soylak and M. Tuzen, J. Hazard. Mater. 137, 1496 (2006).

21. M. Soylak and M. Dogan, Anal. Lett. 29, 635 (1996).

22. X. Wen, Q. Deng and J. Guo, Spectrochim. Acta A 79, 1941 (2011).

23. A. Moghimi, J. Chin. Chem. Soc. 55 , 369 (2008).

24. A.B. Pereiro and A. Rodriguez, Ind. Eng. Chem. Res. 48, 1579 (2009).

25. Z. Gao and X. Ma, Anal. Chim. Acta 702, 50 (2011).

26. P. Berton, E.M. Martinis, L.D. Martinez and R.G. Wuilloud, Anal. Chim. Acta 640, 40 (2009).

27. X. Han and D.W. Armstrong, Acc. Chem. Res. 40, 1079 (2007)

28. J.F. Liu, N. Li, G.B. Jiang, J.M. Liu, J.Å. Jönsson and M.J. Wen, J. Chromatogr. A 1066, 27 (2005).

29. J.F. Peng, J.F. Liu, X.L. Hu and G.B. Jiang, J. Chromatogr. A 1139, 165 (2007).

30. F. Pena-Pereira, I. Lavilla and C. Bendicho, Trends Anal. Chem. 29, 617 (2010).

31. A. Sarafraz-Yazdi and A. Amiri, Trends Anal. Chem. 29, 1 (2010).
32. M. Soylak and E. Yilmaz, Desalination 275, 297 (2011).

33. A.N. Anthemidis, G.A. Zachariadis and J.A. Stratis, J. Anal.At. Spectrom. 18, 1400 (2003).

34. A. Afkhami, T. Madrakian and $\mathrm{H}$. Siampour, J. Hazard. Mater. 138, 269 (2006).

35. A.N. Anthemidis and K.G. Ioannou, Talanta 79, 86 (2009).

36. C. Jianrong and T.K. Chuan, Anal. Chim. Acta 450, 215 (2001).

37. M.A. Farajzadeh, M. Bahram, B. Ghorbani Mehr and J.Å. Jönsson, Talanta 75, 832 (2008).

38. I. Narin, M. Soylak, L. Elci, and M. Dogan, Anal. Lett. 34, 1935 (2001).

39. M. Soylak, and M. Dogan, Trace Elem. Electroly. 13, 130 (1996).

40. M. Soylak, A.U. Karatepe, L. Elci, and M. Dogan, Turk. J. Chem., 27, 235 (2003). 